\title{
KENDALI JARI ROBOT DENGAN ELECTROMYOGRAPHY
}

\author{
Daniel S Pamungkas'), Sumantri R Kurniawan²), Eko Prasetyo ${ }^{3)}$ \\ ${ }^{1,2,3}$ Teknik Elektro, Politeknik Negeri Batam, Jl Ahmad Yani, 29432 \\ e-mail:32prasetyo.eko47@ymail.com
}

\begin{abstract}
Robot fingers can be applied to various activities, one of which is to replace the hands/fingers of someone who lost their hands/fingers. To mobilize the robot can be used several methods one of them is by using muscle sensor. In this study, a pair of electrodes placed on the subject's forearm as well as an artificial finger robot was used. For the open and close the fingers on the robot learning process, the artificial neural network is used. From this research, the proposed system can imitate subject movements with the results are for open and close fingers are $90,2 \%$ and $85,4 \%$ respectively..
\end{abstract}

Key words : finger robot, neural network, electromyography

\begin{abstract}
ABSTRAK
Robot jari dapat diaplikasikan pada berbagai kegiatan, salah satunya adalah untuk mengantikan tangan/jari pada seseorang yang kehilangan tangan/jarinya. Untuk mengerakkan robot tersebut dapat digunakan beberapa metoda salah satunya adalah dengan mengunakan sensor otot. Pada penelitian ini, sepasang elektroda diletakan pada lengan bawah subjek serta sebuah robot jari buatan digunakan. Untuk proses learning membuka dan menutup jari pada robot jari maka digunakan jaringan syaraf tiruan. Dari penelitian ini didapatkan bahwa sistem yang diusulkan dapat mengerakan robot jari sesuai dengan gerakan subjek, yaitu $90,2 \%$ dan $85,4 \%$ untuk gerakan membuka serta menutup.
\end{abstract}

Key words : Jari robot, jaringan syaraf tiruan, electromyograpy

\section{PENDAHULUAN}

Teknologi robot telah banyak diaplikasikan pada kehidupan seharihari.,Salah satu aplikasi adalah untuk membantu penyandang cacat. Robot tangan dapat dimanfaatkan untuk mengantikan tangan dari penyandang cacat yang kehilangan tangannya. Tangan robot dapat dikendalikan dengan beberapa metoda telah dikembangan oleh beberapa peneliti diantaranya adalah dengan mengunakan suara (Ángel-López J.P \& Arzola de la Peña N., 2017), sinyal otak atau Electroencephalography (EEG) (Miskon A., Thanakodi S.,Mazlan M.R., Azhar S., Nooraya S \& Tawil M., 2016) dan sinyal otot atau Elektromyography (EMG) (Akhmadeev K., Rampone E., $\mathrm{Yu}$ T., Aoustin Y \& Carpentier E., 2017). Pengendalian dengan mengunakan sinyal EMG lebih banyak dipakai dibandingkan dengan metoda lainnya karena elektroda EMG lebih murah dan lebih mudah dipasang.

EMG memerlukan teknik membaca sinyal otot dengan cara merekam aktifitas otot. Untuk membaca sinyal tersebut digunakan elektroda yang diletakkan pada/di dalam kulit manusia (Marco E.B, Andrés G.J, Jonathan A.Z., Andrés P., \& Víctor H.A., 2017; Weiss L., Weiss J., \& Silver J., 2016). Karena kepraktisannya maka elektroda yang ditempel pada kulit lebih popular dibandingkan dengan metoda yang lain. Untuk mengendalikan robot tangan mengunakan sinyal ini, diperlukan pengenalan sinyal EMG yang diakibatkan oleh pergerakan tangan penguna. Pengenalan sinyal EMG dapat mengunakan tiga metoda. Metoda tersebut adalah: domain waktu: slope sign changes (SSC), mean absolute value (MAV), waveform length (WL), root mean square (RMS), zero crossing 
(ZC) dan Willison amplitude (WAMP), domain frekuensi: mean power frequency (MPF), fast fourier transform (FFT), median frequency (MF), dan domain waktu-frekuensi yaitu wavelet dan wavelet packet transform (WPT). Metoda-metoda tersebut memiliki kelebihan dan kekurangan. Sebagai contoh: domain waktu adalah metoda yang paling mudah sedangkan metoda frekuensi waktu adalah metoda yang paling stabil. Sementara metoda gabungan domain waktu-frekuensi adalah metoda yang terbaik untuk mengeluarkan sinyal EMG (Shunzhan H., Chenguang Y., Wang M., Cheng L., \& Zedong H., 2017; Arief Z., Indra A.S. \& Roby A.A., 2015).

Beberapa penelitian telah dapat mengenali gerakan-gerakan seperti wave out, wave in, serta mengunakan banyak elektroda untuk membaca geraka otot (Dhito Y. (2017). Pada penelitian kali ini diusulkan pengenalan gerakan mengengam dan membuka seluruh jari dengan mengunakan satu channel saja. Gerakan ini adalah gerakan dasar yang paling dibutuhkan oleh penderita cacat, dan mengunakan elektroda dengan jumlah yang minimum. Sedangkan untuk pengenalan pola dari gerakan membuka dan menutup, digunakan algoritma jaringan syaraf tiruan. Dengan melihat sinyal dengan domain waktu. Dimana sistem ini akan diujikan pada robot tangan.

\section{Tinjauan Pustaka \\ Electromyography}

Electromyography adalah sebuah proses yang digunakan untuk mendeteksi, menganalisa dan juga sebagai pemanfaatan sinyal listrik yang berasal dari kontraksi otot. sinyal yang diperoleh disebut dengan myoelectric. Dalam definisi lain dikatakan elektromyography adalah teknik untuk memantau dan merekam aktifitas sinyal otot pada tubuh manusia dengan keluaran berupa sinyal. Otot yang dipantau adalah otot lurik yaitu otot yang bersifat tidak sadar dan tidak teratur karena aktifitasnya bergantung pada kehendak pelaku (Adi D.I.F., 2017).

Proses untuk memperoleh sinyal EMG dilakukan dengan cara meletakkan elektroda sebagai media penerima. Elektroda dapat diletakkan langsung pada permukaan kulit luar atau dimasukan ke dalam tubuh. Sinyal yang diperoleh oleh elektroda merupakan sinyal acak dari otot yang berkontraksi maupun relaksi. Karakteristik dari sinyal otot EMG mempunyai rentang frekuensi antara $20 \mathrm{~Hz}$ sampai $245 \mathrm{~Hz}$ dan rentang tegangan antara $0,4 \mathrm{~V}$ sampai dengan 5V (Shunzhan H., Chenguang Y., Wang M., Cheng L., \& Zedong H.,2017).

Elektroda yang diletakkan pada permukaan kulit merupakan elektroda yang ditempelkan pada otot yang terdapat di dalam kulit. Dimana pergerakan otot akan dijadikan sebuah sumber sinyal EMG untuk diproses selanjutnya. Elektroda ini mengambil tegangan yang dihasilkan oleh kontraksi serat otot (Dhito Y., 2017).

Sinyal EMG adalah sinyal acak atau stokastik yang amplitudonya berkisar dari $0,4 \mathrm{~V}$ sampai $5 \mathrm{~V}$ dan terdapat amplitudo yang tinggi ketika terjadi kontraksi otot. Serta frekwensi dari sinyal ini mempunyai range antara $20 \mathrm{~Hz}-500 \mathrm{~Hz}$. Sinyal elektrik otot memiliki membrane voltage sekitar 90 milivolt. Sedangkan dengan menggunakan electromyograph terukur antara 50 mikrovolt sampai dengan 20 ke 30 milivolt yang tergantung dari jenis otot yang dimonitor. Sedangkan laju pengulangan dari otot gerak adalah sekitar 7-20 Hz, tergantung dari ukuran otot, kerusakan saraf dan faktor lainnya (Marco E.B, Andrés G.J, Jonathan A.Z., Andrés P., \& Víctor H.A., 2017). 


\section{Supervised Backpropagation Neural Network}

Untuk pengenalan pola gerakan, maka digunakan metoda Supervised Backpropagation Neural Network. Backpropagation merupakan sebuah metoda yang sistematis dimana menggunakan algotirma pembelajaran yang terawasi (supervised) dan biasanya digunakan pada perceptron untuk mengubah nilai dari bobot-bobot pada hidden layer. Backpropagation termasuk jaringan multiLayerperceptron yaitu jaringan yang terdiri dari dua lapisan atau lebih dengan bobot yang dapat diatur antara unit input dengan unit tersembunyi serta antara unit tersembunyi dengan unit output. Seperti yang diperlihatkan pada gambar 1

\begin{abstract}
Gambar 1. Multi-Layerperception
Multi-Layerperceptron terdiri dari beberapa layer node dan pada setiap node terhubung dengan node layer yang berbeda. Fungsi pada input layer adalah menerima sinyal input dari luar, kemudian mendistribusikannya ke semua neuron yang ada pada hidden layer. Fungsi pada hidden layer adalah untuk mendeteksi berat (bobot), hidden yang memiliki maksud 'menyembunyikan' output yang dikehendakinya. Fungsi output layer adalah menerima sinyal output dari hidden layer dan menetapkan pola output bagi keseluruhan jaringan.

Pada gambar 2 terlihat jaringan backpropagation dimana X1, X2, X3 merupakan input, sedangkan Z1 dan Z2 adalah hidden layer dan $\mathrm{Y}$ adalah output. Terdapat bobot vij yang merupakan nilai bobot antara layer input dengan hidden layer dan bobot wij
\end{abstract}

adalah bobot antara hidden layer dengan layer output, b1dan b2adalah bias dimana berfungsi untuk mempercepat pelatihan.

Fungsi aktivasi sigmoid memiliki persamaan sebagai berikut:

$\mathrm{Y}^{\text {sigmoid }}=\frac{1}{1+e^{-\mathrm{x}}}$

Dimana e merupakan bilangan epsilon dan $\mathrm{x}=\sum_{\mathrm{i}=1}^{\mathrm{n}} \mathrm{X}_{\mathrm{i}}(\mathrm{p}) \cdot \mathrm{W}_{\mathrm{ij}}(\mathrm{p})$. Untuk menghitung output aktual dari neuron pada hidden layer:

$\mathrm{Y}_{\mathrm{i}}(\mathrm{p})=\operatorname{sigmoid}\left[\sum_{\mathrm{i}=1}^{\mathrm{n}} \mathrm{X}_{\mathrm{i}}(\mathrm{P}) \cdot \mathrm{W}_{\mathrm{ij}}(\mathrm{P})-\theta_{\mathrm{i}}\right] . .(2)$

Dimana $\theta$ adalah nilai threshold dan $\mathrm{n}$ adalah jumlah neuron input $\mathrm{j}$ pada hidden layer. Untuk menghitung output aktual dari neuron pada layer output:

$\mathrm{Y}_{\mathrm{i}}(\mathrm{p})=\operatorname{sigmoid}\left[\sum_{\mathrm{j}=1}^{\mathrm{m}} \mathrm{X}_{\mathrm{jk}}(\mathrm{P}) . \mathrm{W}_{\mathrm{jk}}(\mathrm{P})-\theta_{\mathrm{k}}\right] \ldots$

Dimana $\mathrm{m}$ adalah jumlah neuron input $\mathrm{k}$ pada output layer. Untuk memperbaharui nilai bobot dari nilai error yang dirambatkan kearah belakang (backward) yang sesuai dengan nilai dari neuron output digunakan persamaan:

$\delta_{k}(P)=Y_{k}(P) \cdot\left[1-Y_{k}(P)\right] \cdot e_{k}(P) \ldots \ldots \ldots(4)$

$\mathrm{e}_{\mathrm{k}}(\mathrm{P})=\mathrm{Y}_{\mathrm{d} . \mathrm{k}}(\mathrm{P})-\mathrm{Y}_{\mathrm{k}}(\mathrm{P})$

Dimana $\delta=$ gradient error (dell). Untuk memperbaharui bobot dari neuron output layer digunakan persamaan:

$\mathrm{w}_{\mathrm{ji}}^{(\mathrm{s})}(\mathrm{k}+1)=\mathrm{w}_{\mathrm{ji}}^{(\mathrm{s})}(\mathrm{k})+\mathrm{w}^{(\mathrm{s})} \delta_{\mathrm{j}}^{(\mathrm{s})} \mathrm{X}_{\mathrm{out}, \mathrm{i}}^{(\mathrm{s}-1)}$ 
Menghitung gradient error dari neuron di hidden layer digunakan persamaan: $\delta_{j}(P)=Y_{j}(P) \cdot\left[1-Y_{j}(P)\right] \cdot \sum_{k=1}^{1} \delta_{k}(P) \cdot w_{j k}(P) \ldots(7)$

Untuk memperbaharui nilai bobot dari neuron hidden layer digunakan persamaan:

$\mathrm{v}_{\mathrm{ji}}^{(\mathrm{s})}(\mathrm{k}+1)=\mathrm{v}_{\mathrm{ji}}^{(\mathrm{s})}(\mathrm{k})+\mathrm{w}^{(\mathrm{s})} \delta_{\mathrm{j}}^{(\mathrm{s})} \mathrm{X}_{\mathrm{out}, \mathrm{i}}^{(\mathrm{s}-1)} \ldots$

\section{METODE PENELITIAN}

\section{Perancangan Perangkat Keras}

Pada penelitian ini akan dibuat sistem pengontrolan pergerakan tangan robot dengan diagram blok seperti pada gambar 3 sebagai berikut:

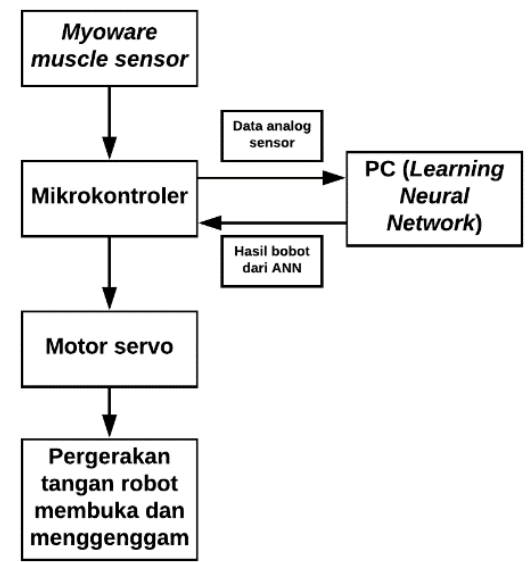

Gambar 3. Diagram Blok Perangkat Keras Pergerakan Tangan Robot

Input tangan robot dari sensor otot dimana keluarannya adalah sinyal EMG. Keluaran sinyal tersebut diproses dengan mikrokontroler dan diubah menjadi data analog. Kemudian data tersebut akan diproses dengan program Artificial Neural Network (ANN) untuk memilah data dan mencari bobot yang sesuai dengan target yang telah ditetapkan. Pada penelitian ini metoda pembelajaran Jaringan syaraf tiruan yang digunakan adalah metoda supervised dengan algoritma backpropagation dan output adalah sigmoid activation. Setelah nilai bobot yang sesuai dengan target telah didapat maka data tersebut akan diproses kembali ke dalam mikrokontroler agar dapat menjalankan motor servo sehingga menghasilkan output pergerakan tangan robot berupa membuka dan menggenggam.

Sensor otot yang digunakan adalah Myoware Muscle Sensor keluaran Advancer Technologies dengan seri (AT-04-001). Dimana sensor ini mampu menangkap sinyal EMG yang dihasilkan oleh otot. Sinyal ini dapat diproses langsung oleh sebuah mikrokontroler. Sensor ini harus dihubungkan dengan 3 buah elektroda untuk dapat mengambil sampel sinyal otot (mid-end-reference electrode) (Brent, n.d). Gambar dari sensor ini dapat dilihat pada gambar 4 .

Sedangkan mikrokontroler yang digunakan adalah arduino AT Mega 250. Mikrokontroler ini juga dipakai untuk mengerakan robot. Robot tangan yang digunakan adalah robot yang diproduksi sendiri. Desain tangan robot diambil dari inmoov project dan dibuat dengan menggunakan proses 3D printing. Tangan robot digerakan menggunakan motor servo yang diikatkan dengan senar. Senar-senar ini berfungsi untuk menggerakan jari-jari tangan dari robot. Sehingga, robot ini dapat mengerakan seluruh jari dengan digerakkan oleh lima buah servo. Gambar robot tangan dapat dilihat pada gambar 5.

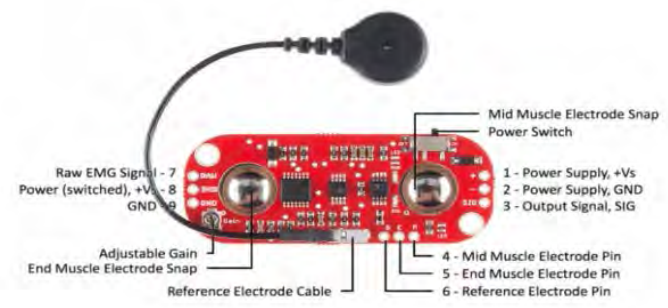

Gambar 4. Myoware Muscle Sensor [7] 
Gambar 5. Tangan Robot

\section{Perancangan Perangkat Lunak}

Pada perancangan perangkat lunak akan dijelaskan mengenai proses kerja dari sistem yang diusulkan. Proses dibagi menjadi dua bagian, bagian pertama merupakan proses learning dengan metoda Jaringan syaraf tiruan dimana mengunakan input berupa sinyal EMG. Sinyal EMG diperoleh dari percobaan yang dilakukan pada tangan subjek dengan melakukan gerakan membuka dan menggenggam. Gerakan ini dilakukan dengan variasi kekuatan dan gerakan pergelangan tangan. Pengambilan data selama masa percobaan dilakukan masing-masing sebanyak 20 kali percobaan. Semua data percobaan tersebut akan dimasukkan kedalam program jaringan syaraf tiruan lalu diberikan nilai threshold yang berfungsi sebagai pembanding nilai dari bobot yang akan dikalkulasikan dan nilai target sebagai acuan.

Bagian kedua dari sistem ini adalah proses pergerakan tangan robot/pengujian, setelah nilai bobot telah didapat dari proses sebelumnya yaitu proses learning. Pada proses ini ketika kondisi tangan subjek membuka maka, robot juga diharapkan ikut membuka serta ketika pada keadaan tangan subjek menggenggam, tangan robot juga akan ikut menggenggam. Flowchart proses dari awal hingga akhir ditunjukkan pada gambar 6 


\section{HASIL DAN PEMBAHASAN}

Data Myoware Muscle Sensor diambil sebanyak 120 data dengan dua kondisi yaitu kondisi pertama ketika tangan menggenggam dan kondisi kedua ketika tangan membuka. Pengambilan data pada tangan menggenggam terdapat tiga macam keadaan yaitu tangan menggenggam biasa, kuat dan tangan menggenggam dengan pergelangan tangan digerakan. Begitu pula pada pengambilan data ketika tangan membuka digunakan keadaan yang sama.

Pengambilan data pada setiap kondisi sebanyak 60 kali yaitu dengan setiap keadaan sebanyak 20 data. Data yang diambil berupa data analog dengan range range $0-255$ Tabel 1 menunjukan nilai hasil percobaan.

Tabel 1 Nilai yang dikeluarkan oleh elektroda

\begin{tabular}{|c|c|c|c|c|c|c|}
\hline \multirow[b]{2}{*}{ No } & \multicolumn{3}{|c|}{ Membuka } & \multicolumn{3}{|c|}{ Menutup } \\
\hline & $\begin{array}{c}\text { Kondisi } \\
\text { Biasa }\end{array}$ & $\begin{array}{c}\text { Kondisi } \\
\text { Kuat }\end{array}$ & $\begin{array}{l}\text { Kondisi } \\
\text { Pergelangan } \\
\text { Tangan } \\
\text { Digerakkan }\end{array}$ & $\begin{array}{c}\text { Kondisi } \\
\text { Biasa }\end{array}$ & $\begin{array}{c}\text { Kondisi } \\
\text { Kuat }\end{array}$ & $\begin{array}{c}\text { Kondisi } \\
\text { Pergelangan } \\
\text { Tangan } \\
\text { Digerakkan }\end{array}$ \\
\hline 1 & 24 & 49 & 58 & 45 & 110 & 157 \\
\hline 2 & 22 & 56 & 60 & 66 & 133 & 167 \\
\hline 3 & 20 & 42 & 59 & 60 & 122 & 167 \\
\hline 4 & 19 & 46 & 46 & 53 & 132 & 167 \\
\hline 5 & 29 & 45 & 60 & 45 & 102 & 167 \\
\hline 6 & 24 & 44 & 59 & 52 & 111 & 161 \\
\hline 7 & 19 & 43 & 46 & 47 & 135 & 165 \\
\hline 8 & 21 & 46 & 54 & 55 & 133 & 129 \\
\hline 9 & 20 & 43 & 54 & 45 & 149 & 131 \\
\hline 10 & 19 & 48 & 53 & 44 & 130 & 153 \\
\hline 11 & 16 & 40 & 60 & 63 & 156 & 163 \\
\hline 12 & 25 & 32 & 58 & 52 & 148 & 150 \\
\hline 13 & 25 & 39 & 54 & 46 & 160 & 141 \\
\hline 14 & 18 & 38 & 63 & 45 & 114 & 112 \\
\hline 15 & 32 & 30 & 61 & 53 & 109 & 119 \\
\hline 16 & 30 & 40 & 52 & 52 & 124 & 126 \\
\hline 17 & 22 & 40 & 47 & 58 & 155 & 117 \\
\hline 18 & 26 & 39 & 44 & 54 & 151 & 145 \\
\hline 19 & 25 & 41 & 53 & 62 & 142 & 127 \\
\hline 20 & 21 & 40 & 62 & 67 & 120 & 135 \\
\hline
\end{tabular}

Hasil percobaan tersebut kemudian dimasukan dalam proses learning yang dilakukan pada sebuah Komputer. Bobot-bobot yang dihasilkan dari proses pembelajaran tersebut kemudian dimasukan dalam mikrokontroler. Untuk menguji keberhasilan sistem ini, maka dicobakan pada seorang subjek 5 kali percobaan. Dimana tangan subjek sebagai input untuk mengerakkan tangan robot. Subjek melakukan 10 kali membuka dan menutup dengan variasi kekuatan dan gerakan dari pergelangan tangan.

Hasil percobaan yang dilakukan pada penelitian ini dapat dilihat pada tabel 2 
dan tabel 3 dengan tanda (v) berarti gerakan tangan robot berhasil mengikuti gerakan tangan subjek. Sedangkan tanda (x) berarti sebaliknya. Dari hasil percobaan tersebut maka tangan robot berhasil mengikuti pergerakan subjek sebesar 90\% untuk pergerakan tangan membuka dan $85.34 \%$ untuk pergerakan tangan menggenggam. Gambar 7 dan 8 menunjukan gerakan membuka dan menutup yang berhasil ditiru oleh robot tangan.

Tabel 2. Membuka pada robot

\begin{tabular}{|c|c|c|c|c|c|c|c|c|c|c|c|c|c|c|c|}
\hline \multicolumn{4}{|c|}{1} & \multicolumn{3}{|c|}{2} & \multicolumn{3}{|c|}{3} & \multicolumn{3}{|c|}{4} & \multicolumn{3}{|c|}{5} \\
\hline No & $\begin{array}{c}\text { Kondisi } \\
\text { Biasa }\end{array}$ & $\begin{array}{c}\text { Kondisi } \\
\text { Kuat }\end{array}$ & $\begin{array}{c}\text { Kondisi } \\
\text { Lengan } \\
\text { Bawah } \\
\text { Tangan } \\
\text { Digerakkan }\end{array}$ & $\begin{array}{c}\text { Kondisi } \\
\text { Biasa }\end{array}$ & $\begin{array}{l}\text { Kondisi } \\
\text { Kuat }\end{array}$ & $\begin{array}{l}\text { Kondisi } \\
\text { Lengan } \\
\text { Bawah } \\
\text { Tangan } \\
\text { Digerakkan }\end{array}$ & $\begin{array}{c}\text { Kondisi } \\
\text { Biasa }\end{array}$ & $\begin{array}{c}\text { Kondisi } \\
\text { Kuat }\end{array}$ & $\begin{array}{c}\text { Kondisi } \\
\text { Lengan } \\
\text { Bawah } \\
\text { Tangan } \\
\text { Digerakkan }\end{array}$ & $\begin{array}{c}\text { Kondisi } \\
\text { Biasa }\end{array}$ & $\begin{array}{c}\text { Kondisi } \\
\text { Kuat }\end{array}$ & $\begin{array}{c}\text { Kondisi } \\
\text { Lengan } \\
\text { Bawah } \\
\text { Tangan } \\
\text { Digerakkan }\end{array}$ & $\begin{array}{c}\text { Kondisi } \\
\text { Biasa }\end{array}$ & $\begin{array}{c}\text { Kondisi } \\
\text { Kuat }\end{array}$ & $\begin{array}{c}\text { Kondisi } \\
\text { Lengan } \\
\text { Bawah } \\
\text { Tangan } \\
\text { Digerakkan }\end{array}$ \\
\hline 1 & $\mathrm{v}$ & $\mathrm{v}$ & $\mathrm{v}$ & $\mathrm{v}$ & $\mathrm{v}$ & $\mathrm{v}$ & $\mathrm{v}$ & $\mathrm{v}$ & $\mathrm{v}$ & $\mathrm{v}$ & $\mathrm{v}$ & $\mathrm{v}$ & $\mathrm{v}$ & $\mathrm{v}$ & $\mathrm{v}$ \\
\hline 2 & $\mathrm{v}$ & $\mathrm{v}$ & $\mathrm{x}$ & $\mathrm{v}$ & $\mathrm{v}$ & $\mathrm{v}$ & $\mathrm{v}$ & $\mathrm{v}$ & $\mathrm{v}$ & $\mathrm{v}$ & $\mathrm{v}$ & $\mathrm{v}$ & $\mathrm{v}$ & $\mathrm{v}$ & $x$ \\
\hline 3 & $\mathrm{v}$ & $\mathrm{v}$ & $\mathrm{v}$ & $\mathrm{v}$ & $\mathrm{v}$ & $\mathrm{v}$ & $\mathrm{v}$ & $\mathrm{v}$ & $\mathrm{x}$ & $\mathrm{v}$ & $\mathrm{v}$ & $\mathrm{v}$ & $\mathrm{v}$ & $\mathrm{v}$ & $\mathrm{v}$ \\
\hline 4 & $\mathrm{v}$ & $\mathrm{x}$ & $\mathrm{v}$ & $\mathrm{v}$ & $\mathrm{v}$ & $\mathrm{v}$ & $\mathrm{v}$ & $\mathrm{v}$ & $\mathrm{v}$ & $\mathrm{v}$ & $\mathrm{v}$ & $\mathrm{x}$ & $\mathrm{v}$ & $\mathrm{v}$ & $\mathrm{v}$ \\
\hline 5 & $\mathrm{v}$ & $\mathrm{v}$ & $\mathrm{x}$ & $\mathrm{v}$ & $\mathrm{v}$ & $\mathrm{x}$ & $\mathrm{v}$ & $\mathrm{v}$ & $\mathrm{v}$ & $\mathrm{v}$ & $\mathrm{v}$ & $\mathrm{v}$ & $\mathrm{v}$ & $x$ & $\mathrm{v}$ \\
\hline 6 & $\mathrm{v}$ & $\mathrm{v}$ & $x$ & $\mathrm{v}$ & $\mathrm{v}$ & $\mathrm{v}$ & $\mathrm{v}$ & $\mathrm{v}$ & $\mathrm{v}$ & $\mathrm{v}$ & $\mathrm{x}$ & $\mathrm{x}$ & $\mathrm{v}$ & $\mathrm{v}$ & $\mathrm{v}$ \\
\hline 7 & $\mathrm{v}$ & $x$ & $\mathrm{v}$ & $\mathrm{v}$ & $\mathrm{v}$ & $\mathrm{v}$ & $\mathrm{v}$ & $\mathrm{v}$ & $\mathrm{v}$ & $\mathrm{v}$ & $\mathrm{v}$ & $\mathrm{x}$ & $\mathrm{v}$ & $x$ & $x$ \\
\hline 8 & $\mathrm{v}$ & $\mathrm{v}$ & $\mathrm{v}$ & $\mathrm{v}$ & $\mathrm{v}$ & $\mathrm{v}$ & $\mathrm{v}$ & $\mathrm{v}$ & $\mathrm{v}$ & $\mathrm{v}$ & $\mathrm{v}$ & $\mathrm{v}$ & $\mathrm{v}$ & $\mathrm{v}$ & $\mathrm{v}$ \\
\hline 9 & $\mathrm{v}$ & $\mathrm{v}$ & $\mathrm{v}$ & $\mathrm{v}$ & $\mathrm{v}$ & $\mathrm{v}$ & $\mathrm{v}$ & $\mathrm{v}$ & $\mathrm{v}$ & $\mathrm{v}$ & $\mathrm{v}$ & $\mathrm{v}$ & $\mathrm{v}$ & $\mathrm{v}$ & $\mathrm{v}$ \\
\hline 10 & $\mathrm{v}$ & $\mathrm{v}$ & $\mathrm{v}$ & $\mathrm{v}$ & $\mathrm{v}$ & $\mathrm{v}$ & $\mathrm{v}$ & $\mathrm{v}$ & $\mathrm{v}$ & $\mathrm{v}$ & $\mathrm{v}$ & $\mathrm{v}$ & $\mathrm{v}$ & $\mathrm{v}$ & $\mathrm{v}$ \\
\hline
\end{tabular}

Tabel 3. Menutup pada robot

\begin{tabular}{|c|c|c|c|c|c|c|c|c|c|c|c|c|c|c|c|}
\hline \multicolumn{4}{|c|}{1} & \multicolumn{3}{|c|}{2} & \multicolumn{3}{|c|}{3} & \multicolumn{3}{|c|}{4} & \multicolumn{3}{|c|}{5} \\
\hline No & $\begin{array}{c}\text { Kondisi } \\
\text { Biasa }\end{array}$ & $\begin{array}{l}\text { Kondisi } \\
\text { Kuat }\end{array}$ & $\begin{array}{c}\text { Kondisi } \\
\text { Lengan } \\
\text { Bawah } \\
\text { Tangan } \\
\text { Digerakkan }\end{array}$ & $\begin{array}{c}\text { Kondisi } \\
\text { Biasa }\end{array}$ & $\begin{array}{c}\text { Kondisi } \\
\text { Kuat }\end{array}$ & $\begin{array}{c}\text { Kondisi } \\
\text { Lengan } \\
\text { Bawah } \\
\text { Tangan } \\
\text { Digerakkan }\end{array}$ & $\begin{array}{c}\text { Kondisi } \\
\text { Biasa }\end{array}$ & $\begin{array}{l}\text { Kondisi } \\
\text { Kuat }\end{array}$ & $\begin{array}{c}\text { Kondisi } \\
\text { Lengan } \\
\text { Bawah } \\
\text { Tangan } \\
\text { Digerakkan }\end{array}$ & $\begin{array}{l}\text { Kondisi } \\
\text { Biasa }\end{array}$ & $\begin{array}{c}\text { Kondisi } \\
\text { Kuat }\end{array}$ & $\begin{array}{c}\text { Kondisi } \\
\text { Lengan } \\
\text { Bawah } \\
\text { Tangan } \\
\text { Digerakkan }\end{array}$ & $\begin{array}{c}\text { Kondisi } \\
\text { Biasa }\end{array}$ & $\begin{array}{l}\text { Kondisi } \\
\text { Kuat }\end{array}$ & $\begin{array}{c}\text { Kondisi } \\
\text { Lengan } \\
\text { Bawah } \\
\text { Tangan } \\
\text { Digerakkan }\end{array}$ \\
\hline 1 & $\mathrm{v}$ & $\mathrm{v}$ & $\mathrm{v}$ & $\mathrm{v}$ & $\mathrm{v}$ & $\mathrm{x}$ & $\mathrm{x}$ & $\mathrm{v}$ & $\mathrm{v}$ & $\mathrm{v}$ & $\mathrm{v}$ & $\mathrm{v}$ & $\mathrm{v}$ & $\mathrm{v}$ & $\mathrm{v}$ \\
\hline 2 & $x$ & $\mathrm{v}$ & $\mathrm{v}$ & $\mathrm{v}$ & $\mathrm{v}$ & $\mathrm{x}$ & $\mathrm{x}$ & $\mathrm{v}$ & $\mathrm{v}$ & $\mathrm{v}$ & $\mathrm{v}$ & $\mathrm{v}$ & $x$ & $\mathrm{v}$ & $\mathrm{v}$ \\
\hline 3 & $\mathrm{x}$ & $\mathrm{v}$ & $\mathrm{v}$ & $\mathrm{x}$ & $\mathrm{v}$ & $\mathrm{v}$ & $\mathrm{v}$ & $x$ & $\mathrm{v}$ & $\mathrm{v}$ & $\mathrm{v}$ & $\mathrm{v}$ & $\mathrm{v}$ & $\mathrm{v}$ & $\mathrm{v}$ \\
\hline 4 & $\mathrm{v}$ & $\mathrm{v}$ & $\mathrm{v}$ & $\mathrm{x}$ & $\mathrm{v}$ & $\mathrm{v}$ & $\mathrm{x}$ & $\mathrm{v}$ & $\mathrm{x}$ & $\mathrm{v}$ & $\mathrm{v}$ & $\mathrm{v}$ & $\mathrm{x}$ & $\mathrm{v}$ & $\mathrm{v}$ \\
\hline 5 & $\mathrm{v}$ & $\mathrm{v}$ & $\mathrm{v}$ & $\mathrm{v}$ & $\mathrm{v}$ & $\mathrm{v}$ & $\mathrm{v}$ & $\mathrm{v}$ & $\mathrm{v}$ & $\mathrm{v}$ & $\mathrm{x}$ & $\mathrm{v}$ & $\mathrm{v}$ & $\mathrm{v}$ & $\mathrm{x}$ \\
\hline 6 & $\mathrm{v}$ & $\mathrm{v}$ & $\bar{x}$ & $\mathrm{v}$ & $\mathrm{v}$ & $\mathrm{v}$ & $\mathrm{v}$ & $\mathrm{v}$ & $\mathrm{v}$ & $\mathrm{v}$ & $\mathrm{v}$ & $\mathrm{v}$ & $\mathrm{v}$ & $\mathrm{v}$ & $\mathrm{v}$ \\
\hline 7 & $\mathrm{v}$ & $\mathrm{v}$ & $\mathrm{x}$ & $\mathrm{v}$ & $\mathrm{v}$ & $\mathrm{v}$ & $\mathrm{v}$ & $\mathrm{v}$ & $\mathrm{v}$ & $\mathrm{v}$ & $\mathrm{v}$ & $\mathrm{v}$ & $\mathrm{v}$ & $\mathrm{v}$ & $\mathrm{v}$ \\
\hline 8 & $\mathrm{v}$ & $\mathrm{v}$ & $\mathrm{v}$ & $\mathrm{v}$ & $\mathrm{v}$ & $\mathrm{x}$ & $\mathrm{v}$ & $\mathrm{v}$ & $\mathrm{v}$ & $\mathrm{v}$ & $\mathrm{x}$ & $\mathrm{x}$ & $\mathrm{v}$ & $\mathrm{v}$ & $\mathrm{v}$ \\
\hline 9 & $\mathrm{v}$ & $\mathrm{v}$ & $\mathrm{v}$ & $\mathrm{v}$ & $\mathrm{v}$ & $\mathrm{v}$ & $\mathrm{v}$ & $x$ & $\mathrm{v}$ & $x$ & $\mathrm{v}$ & $\mathrm{v}$ & $\mathrm{v}$ & $\mathrm{v}$ & $\mathrm{v}$ \\
\hline 10 & $\mathrm{v}$ & $\mathrm{v}$ & $\mathrm{v}$ & $\mathrm{v}$ & $\mathrm{v}$ & $\mathrm{v}$ & $\mathrm{v}$ & $\mathrm{v}$ & $\mathrm{v}$ & $\mathrm{v}$ & $\mathrm{v}$ & $\mathrm{v}$ & $\mathrm{v}$ & $\mathrm{v}$ & $\mathrm{v}$ \\
\hline
\end{tabular}

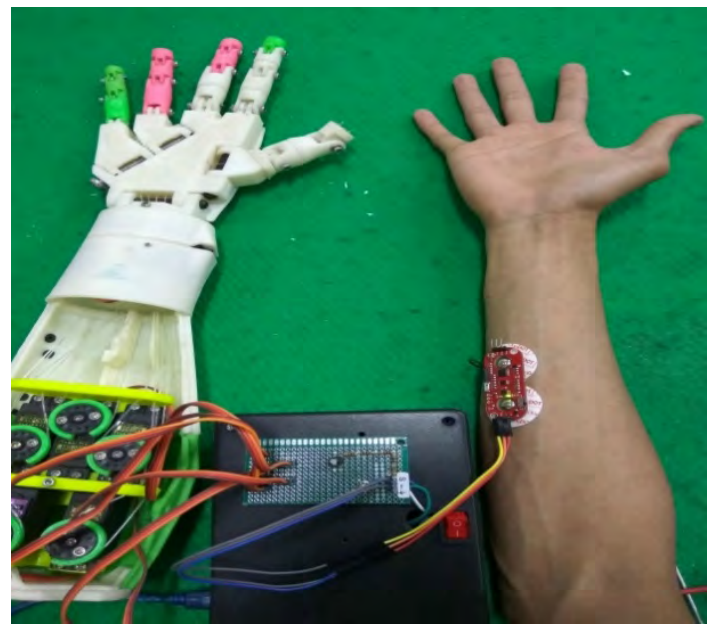

Gambar 7. Posisi Tangan Membuka 


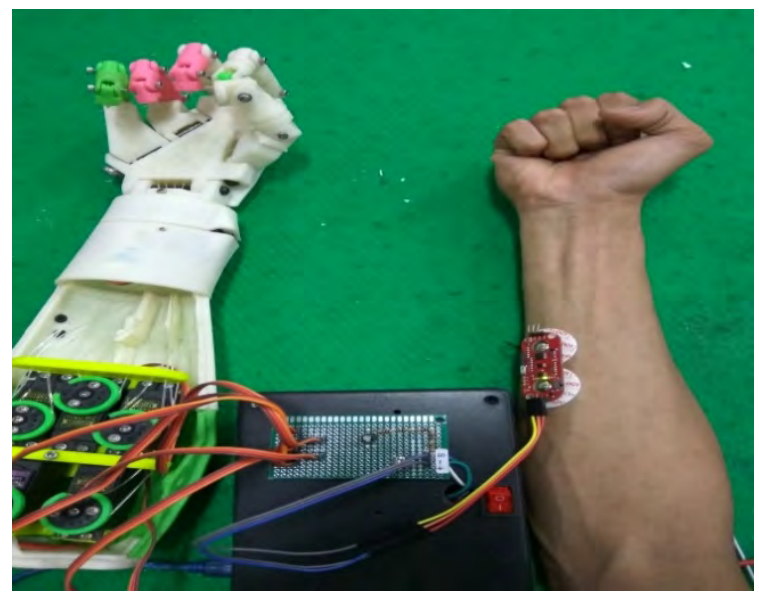

Gambar 8. Posisi Tangan Menggenggam

\section{KESIMPULAN}

istem yang diusulkan dengan hanya mengunakan satu buah sensor yang memiliki 3 elektroda, serta mengunakan algoritma jaringan syaraf tiruan mempunyai keberhasilan untuk meniru gerakan sederhana yaitu membuka dan menutup. Untuk penelitian lebih lanjut perlu dikembangan untuk gerakan yang lebih rumit.

\section{UCAPAN TERIMAKASIH}

enutup. Untuk penelitian lebih lanjut perlu dikembangan untuk gerakan yang lebih rumit.

\section{DAFTAR PUSTAKA}

[1] Ángel-López J.P \& Arzola de la Peña N. (2017) Voice Controlled Prosthetic Hand with Predefined Grasps and Movements. In: Torres I., Bustamante J., Sierra D. (eds) VII Latin American Congress on Biomedical Engineering CLAIB 2016, Bucaramanga, Santander, Colombia, October 26th -28th, 2016. IFMBE Proceedings, vol 60. Springer, Singapore

[2] Miskon A., Thanakodi S.,Mazlan M.R., Azhar S., Nooraya S \& Tawil M. (2016) Viability of
Controlling Prosthetic Hand Utilizing Electroencephalograph (EEG) Dataset Signal. IOP Conference Series: Materials Science and Engineering vol 160 012114

[3] Akhmadeev K., Rampone E., Yu T., Aoustin $\mathrm{Y}$ \& Carpentier $\mathrm{E}$ (2017). A real-time gesture classification using surface EMG to control a robotics hand. ENOC 2017 , Budapest, Hungary

[4] Marco E.B, Andrés G.J, Jonathan A.Z., Andrés P., \& Víctor H.A. (2017) "Hand Gesture Recognition Using Machine Learning and the Myo Armband.", in 25th European Signal Processing Conference (EUSIPCO).

[5] Weiss L., Weiss J., \& Silver J., (2016) "Easy EMG”, Elsevier.

[6] Shunzhan H., Chenguang Y., Wang M., Cheng L., \& Zedong H.(2017). Hand Gesture Recognition using MYO Armband., in Chinese Automation Congress (CAC).

[7] Arief Z., Indra A.S. \& Roby A.A. (2015). "Comparison of Five Time Series EMG Features Extraction Using Myo Armband.”, International Electronics Symposium (IES), Politeknik Negeri Surabaya (PENS), Surabaya, 2015 
[8] Dhito Y. (2017) Muscle Fatigue Detection Using Emg Signal And Force Detector On The Basic Movement Of Extention And Flexion Knee-Joint For Evaluating Use Of Functional Electrival Stimulation On The Lower Limb Rehabilitation System., Final Project - TE 141599, Sepuluh Nopember Institute of Technology, Surabaya

[9] Adi D.I.F., (2017). Klasifikasi Sinyal EMG dari Otot Lengan Sebagai Media Kontrol Menggunakan Naives Bayes., M.A. thesis, Institut Teknologi Sepuluh Nopember, Surabaya

[10] brent. "Myoware Muscle Sensor Kit”, Retrieved from https://learn.sparkfun.com/tutorial s/ 
Daniel S Pamungkas dkk, Kendali Jari Robot... 